
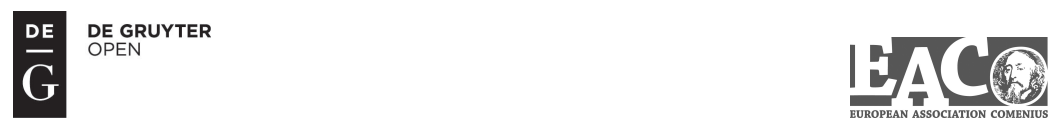

\title{
Corruption ANd System Change in THE CZECH RePublic: FIRM-LEVEL EVIDENCE
}

\section{Petra Koudelková ${ }^{1}$, Wadim Strielkowski ${ }^{2}$, Denisa Hejlová ${ }^{3}$}

\begin{abstract}
Corruption is a widespread phenomenon in all countries undergoing market transition. However, the Czech Republic stands apart, with its incredible entanglement of corruption, politics and business. Although corruption on the firm level in the Czech Republic is heavily criticized, the results of our in-depth interviews conducted with Czech SMEs showed that almost every firm has encountered some form of corruption and even used corruption to either increase sales, help negotiations, or increase production. Most of our respondents admitted that corruption was useful for day-to-day business.

This article aims to obtain information about the state of corruption in enterprises in the Czech Republic and map the behaviour of entrepreneurs in companies.

Our results offer ways to fight corruption: apart from highlighting the negative traits of corruption, emphasis should be made on determining to what extent corruption would be acceptable for firms and their clients. This could be useful for designing various state policies that might influence system change and market development in CEECs and both directly and indirectly influence the volume of corruption.
\end{abstract}

\section{Keywords}

Corruption, Types of Corruption, Firm-level Corruption, Corruption in the Czech Republic, Corruption in Post-communistic Countries

\section{Introduction}

In the past few years, corruption has become a widespread phenomenon in many countries of Central and Eastern Europe (CEECs), including the Czech Republic, see e.g. Lízal and Kocenda (2001), Zuzowski (2004), Wallace and Latcheva (2006) and OECD report

\footnotetext{
${ }^{1}$ Department of marketing communication and PR, Faculty of Social Sciences, Charles University in Prague, Smetanovo nábřeží 6, 11001 Praha 1, Czech Republic. E-mail: koudelkova@fsv.cuni.cz.

${ }^{2}$ Department of marketing communication and PR, Faculty of Social Sciences, Charles University in Prague, Smetanovo nábřeží 6, 11001 Praha 1, Czech Republic. E-mail: strielkowski@fsv.cuni.cz.

${ }^{3}$ Department of marketing communication and PR, Faculty of Social Sciences, Charles University in Prague, Smetanovo nábřeží 6, 11001 Praha 1, Czech Republic. E-mail: hejlova@fsv.cuni.cz.
} 
(2010). Trust in government officials, businesses and media has decreased (Kasl Kollmannová, 2012) and petty corruption has become widespread in CEECs (Jancsics, 2013). In 2013, the Czech Republic topped the list of countries worldwide with a free press in terms of corruption, with $94 \%$ of respondents stating that "corruption is widespread in government", contrary to Sweden (14\%), Denmark (15\%) or Switzerland (23\%). The alarming number of Czech citizens who mistrust their government officials equals the level of trust in countries with only a partially free press or no freedom of speech at all, such as Nigeria, Chad or Uganda. Other researches, such as the study on the corruption climate in the Czech Republic conducted by GfK (2010), or the Corruption Perceptions Index, issued yearly by Transparency International (2013), also rank the Czech Republic among those countries with the highest level of perceived corruption. However, the lack of trust in government officials due to perceived corruption is also very high in economically developed countries such as Greece (92\%), Lithuania (90\%), Portugal (88\%) or Italy (86\%). Corruption scandals are notorious in Czech politics and most recently one such scandal caused the collapse of Petr Nečas' Civic Democratic government in June 2013. Corruption and fraud emerged as a major issue as a consequence of the loss of public trust, followed by the economic crisis in 2008 (Edelman, 2013). One might assume that the low level of trust and highly perceived corruption is linked to the recent economic crisis, such as in Portugal, Greece or Italy, but that does not account for countries like Lithuania or the Czech Republic, which have not been affected by the economic crisis to such a great extent. Moreover, contrary to the popular belief that economic growth and transition towards full democracy brings with it decreasing tolerance for corruption and higher transparency, the Czech Republic demonstrates the opposite trend (Gupta, Ham and Švejnar, 2000). According to GfK (2010), people's attitudes toward corruption have changed towards acceptance of such practices as the norm. Every fifth Czech citizen declares that he or she personally knows someone who takes or has taken bribes, i.e. $20 \%$ versus the EU average of $12 \%$, according to the European Commission (2014, p. 8). According to GfK research on the corruption climate in the Czech Republic conducted for Transparency International, $48 \%$ of Czech citizens gave a bribe at least once in 2009 (Mravec, 2012). Therefore, the aim of this article is to examine the determinants of corruption in the Czech Republic, a country where almost every citizen of this 10 million-strong nation seems to perceive her or his country as "corrupted", see Lízal and Kocenda (2001), Jordan (2002) or Stephen (2007).

Generally, there are several definitions of corruption that can be used as a benchmark. For instance, Transparency International uses the following definition: "corruption, defined as the misuse of public power for private benefit". The Ministry of the Interior of the Czech Republic offers a somewhat more detailed definition: "corruption can be characterized as a relationship between two subjects, both individuals and institutions, in which one party offers, or serves, the other party some form of remuneration for providing or committing to provide an unjustified favour. The providing party then expects some form of tangible or intangible favour for the favour it provided. In the CEECs this process can be found in the state government, politics and business. Graycar and Prenzler offer a comprehensive approach when defining corruption based on the TASP model of analysis, which 
differentiates corruption according to types, activities, sectors and places" (Graycar and Prenzler, 2013).

This paper focuses on corruption and system change in the Czech Republic, with a special stress on corruption at the firm level. This paper tries to obtain information about corruption behaviour in enterprises in the Czech Republic. The paper is structured as follows: First, it describes the problematique of corruption internationally in general, and corruption in the CEECs represented by the Czech Republic in particular. Second, it analyses corruption at the firm level. Third, it presents several case studies from the Czech Republic that describe the situation in the surveyed Czech SMEs. Fourth, it concentrates on the quantitative research that reports the results of the anonymous questionnaire that aimed at finding out whether corruption in the Czech Republic is widespread at the firm level, or whether Czech SMEs try to fight corruption. A very important aspect of our research was to determine who is most often associated with corruption at the firm level. Our results are corroborated by the findings of Transparency International (for instance, the CPI index) and other established research agencies and researchers dealing with corruption in the Czech Republic.

\section{Corruption and its forms: state-of-the-art}

Bureaucratic corruption is pervasive throughout the world. It seems that not all countries in the world have suffered from widespread corruption, while some countries have coped well (Wang and You, 2012). In more economically developed countries, governments try to fight corruption (Otáhal, 2006). This explains the fact that the majority of academic research studies deal with state-level corruption. According to the best of our knowledge, very few researchers study corruption at the firm level. However, corporate corruption and corruption in firms, which are among the many challenges facing public service institutions in developing countries, is one of the most pervasive and difficult of these challenges to solve (Berg, Jiang and Lin, 2012). According to Dijk and Nguyen (2012), there are three major reasons for this form of corruption to be of special concern. First, country-level research does not help us understand the factors of the level of corruption that individual firms face. Second, firm-level analysis is crucial for understanding why and how the impact of corruption differs across firms. Third, firm-level studies can have important policy implications and could, for example, provide countries with a high level of corruption with recommendations on which local institutions matter with regard to the prevalence of corruption. Dijk and Nguyen (2012) show that those individuals most engaged in corruption on an everyday basis are politicians working in the sector of public services, as well as others who control public offices and their financial flows.

The basic attributes of corruption might be classified as follows:

\section{1) Corruption according to location (Klitgaard and Maclean, 2000)}

- Internal corruption (among public servants),

- Political corruption (entanglement of politics with the private and business sector),

- State-level corruption (corruption emerging from handling public property), 
- Public sector corruption (e.g. law enforcement agencies, judicial system, etc.)

- Private sector corruption (interconnected with public sector corruption - e.g. the misuse of public tenders),

- Mass media corruption (manipulation of information)

- Municipal-level corruption (e.g. autonomous regions, majors, self-governments, etc.)

In accordance with the classification presented above, all forms of corruption have the same origin in the public sector (including corruption that can be traced in the private sector, a fact which is proved by the reports of some anticorruption organizations). Nevertheless, the private sector yields its own specific forms of corruption.

\section{2) Corruption according to the form (e.g. Batory, 2012; Mauro, 1995; or Besley and McLaren, 1993)}

- Nepotism (corrupt behaviour which consists of favouring family members within the employment; however, when the company is given to family members to run and own, this is called "family business" and does not have traces of nepotism.

- Clientelism (favouring friends, relatives or interest groups, very often happens through favouring the companies that supported the given firm in the past - overall, this is a very widespread form of corruption)

- Bribery (another widespread form of corruption)

- Lobbying (very negatively perceived activity in the Czech Republic - used to be called "the clash of interests", a definition which is now non-existent).

Corruption can influence society in a number of ways. The research literature describes corruption at the country level judging from various viewpoints. The following determinants of corruption are often mentioned: rent seeking opportunities, corporate competition (Ades, Di Tella, 1999), legal effectiveness (Herzfeld, Weiss, 2003) and legal origin, religion, status of economic development (Paldam, 2002; Dijk, Nguyen, 2012). In general, there are two points of view of corruption, the first states that corruption negatively impacts on national economy and economic growth (North, 1990; Li et al, 2000) and on human capital (Mo, 2001). The slowing down of economic growth happens due to the fact that corruption reduces investments (Mauro, 1995).

Corruption can be viewed as a tax on the profits of the productive sector which allows entry into the market for those new products and technologies which require initial fixed costs or investment (Murphy et al., 1991). On the other hand, there is another view in the research literature that says that corruption actually increases efficiency and helps economic growth, particularly in developing countries (Lui, 1985). The breeding ground of corruption is represented by the weak points of the normative system at the cross level, as well as the firm level (Merton, 1961), which occurs in three cases. Firstly, there are more standards that are mutually exclusive and the individual does not know how to behave. In addition, there are cases where compliance does not lead to the desired and promised incentives. The last case is the absence of these norms (Merton, 1961; Staniszkis, 2009). 
Standard economic theory predicts that government intervention transfers resources away from the private sector and provides opportunities for corruption. If economic freedom increases sufficiently, then the level of corruption tends to fall, and it continues to fall as the quality of institutions gradually improves (Pieroni, d'Agostino, 2013). The aforementioned authors attempted to find a connection between economic freedom and corruption. Their results are consistent with claims by other authors (Graeff, Mehlkop, 2003) who say that while cross-country regressions of economic freedom and corruption give results in line with the prevailing view, that corruption is reduced by an increase in economic freedom, this may hide heterogeneity at the sectorial level, particularly in the degree and nature of government intervention. Some government regulations may have the effect of increasing the transaction costs of corruption (Lambsdorff, 2007; Emerson, 2006).

Apart from the proponents of laissez-faire theory, e.g. Bliss and Di Tella (1997), there is another viewpoint which, on the contrary, considers state intervention to be right and claims that it is not appropriate to have economic freedom because state regulation helps to reduce corruption, see e.g. Graeff and Mehlkop (2003), Paldam (2002). As one can see, it is necessary to find an exact measure of how much state regulation there is in the field of corruption and the extent to which corruption does not become a problem of society and the national economy.

Generally, corruption is part of the larger family of the so-called "gray economy", which affects the national economy and especially the ability of the state to collect taxes, see Schneider et al. (2010), Kaufmann (2010), Cooray, Schneider (2013). Illegal employment is also part of the shadow economy (Schneider, 2014). This phenomenon is general - we can even say "expected" - because there were 119.6 million people in the EU living in poverty and social exclusion in 2011 (Birčiáková, Stávková, Antošová, 2013)

The European Union is attempting to combat this problem (Schneider, 2014). Shadow economies are a complex phenomenon present to a significant extent in developing, transition as well as highly-developed economies (Buehn, Schneider, 2011; Johnson, 1997).

Smith (1994) defines the shadow economy as that "market-based production of goods and services, whether legal or illegal that escapes detection in the official estimates of GDP" (Smith, 1994, p. 18). It is clear that a broad definition of the shadow economy includes unreported income from the production of legal goods and services, either from monetary or barter transactions (Schneider, 2013, p. 3).

\section{Short characteristics of the Czech firm-level sector}

About $99.84 \%$ of all SMEs in the Czech Republic are represented by small and medium enterprises (SMEs) (MPO, 2012). SMEs constitute a backbone of the Czech economy, both in microeconomic and macroeconomic terms. They are of special importance for the development of the national economy both in terms of job creation, as well as for the social and economic development of communities, cities and regions, increasing market dynamics and contributing to the stabilization of the economic system, thanks to their ability to absorb free labour. There is a plethora of comprehensive research literature on SMEs, see, e.g. Flatten, Brettel (2011). SMEs have their major advantages (flexibility) 
and disadvantages (e.g. lack of funds). Unlike large companies, where management and ownership are separated, SMEs are mostly owner-managers. Sometimes, SMEs conflate corporate goals with personal ones (Favre-Bont, Thevenard-Puthod, 2013), which can be another disadvantage. The issue of ownership is also discussed in many studies (Hamadi, 2010).

SMEs constitute strong support for a decentralized system that has characteristics inherited from the market economy. For the Czech Republic and its position in Europe, SMEs represent a key issue. Zelený (2003) says: “small countries like the Czech Republic need to build competitive advantage based on the autonomy of local business networks, rather than the macroeconomic centralize the dictates of the state and its companies - giants. Networks of small, flexible and technologically agile enterprises, regionally conceived and developed locally, not derive only from their successes (foreign) financial capital, but from the knowledge, skills, innovation, adaptability, flexibility and entrepreneurship human beings. Competitive advantages can only create these individual and local capabilities." (Zelený, 2003, p. 94).

Doing business in the Czech Republic became possible only after 1989. The Czech Republic, as one of the post-communist countries, became part of the phenomenon of corruption, which had roots in our society since the time of the Soviet bloc (Jordan, 2002). At that time, after the collapse of the Soviet bloc, the people were taught concepts which could be freely translated as "he who does not steal from the state, robs his own family". This statement still remains deeply anchored in Czech society, especially in those people who were part of communist society or received a communist education.

In the Czech Republic, the most active entrepreneurial people are those from 18 to 35 years of age, with the most business entities registered in Prague. It is estimated that across the whole country there are 554,000 people who own and manage their own business (see Figure 1). Citizens of the Czech Republic display high interest in business, as shown in the survey which was conducted by the University of Economics in Prague in cooperation with the Ministry of Trade and Industry. The results of the survey showed that $14 \%$ of respondents between 18-64 years of age are about to start their own business within three years. The results also show that about $70 \%$ of entrepreneurs decided to start their own business because it was seen as a great opportunity and not out of necessity (Očko, 2012). However, in comparison with other countries, $30 \%$ of respondents claimed that they do business out of necessity, which is still a high number.

When one looks at the number of small and medium-sized enterprises, and according to the latest data, by December 31, 2012, a total of 1,122,511 legal and natural persons carried out business activity (employing 0-249), 851,178 were sole traders (employing 0-249) and there were 271,333 legal entities (employing 0-249) (MIT, 2013; Czech statistical office, 2013) . 
Figure 1: Development of number of employees in Czech SMEs in 2013 (in thousands)

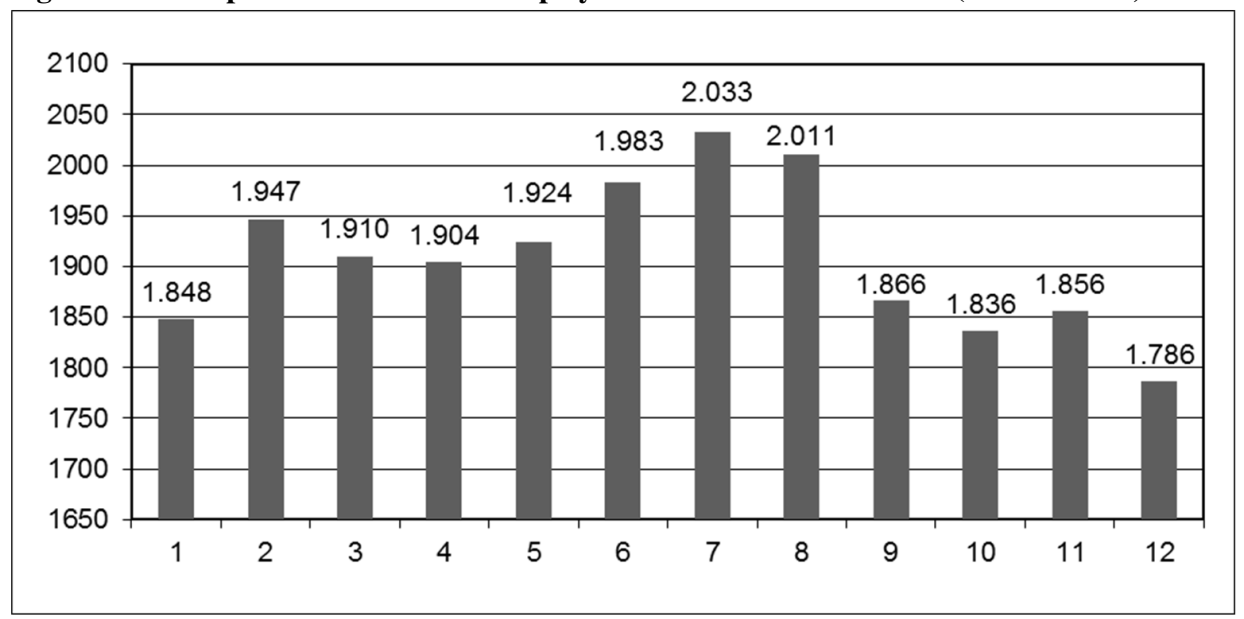

Source: CZSO (2013), MPO (2013)

In Figure 1 above you can see the development of the number of employees in Czech Republic. The $x$ axis shows months and $y$ shows number of employees in thousands. Figure 1 makes it apparent that in 2013 there was only a slight increase in the number of employees in SMEs, by 20,000, to a total of 1,856 thousand employees. This is an increase, but there is still a trend persisting from 2010, which started after the onset of the financial crisis in 2009. In 2012 a contrary movement occurred, with a significant decrease of 70,000 workers.

\section{Corruption in the Czech Republic}

As Jordan (2002) stated, "Corruption was endemic to the Communist system of the Soviet bloc prior to its collapse in 1989, and Czechoslovakia was no exception. In the postcommunist Czech Republic, corruption remains a deeply rooted problem". The level of corruption in transition markets, especially the Czech Republic, has been examined by Lízal and Kocenda (2001), who stated that a "substantial change of approach to the institutional framework is necessary in order to prevent and fight corruption successfully" (Lízal and Kocenda, 2001, p. 141). Many authors have examined the role of corruption in transition economies in the CEE, including the Czech Republic, see, e.g. Lízal and Kocenda (2001), Janowicz et al. (2004), or Vedres (2007), especially the corruption climate and its role in privatization (Bornstein, 1999; Nandini, Ham and Švejnar, 2000; Evans and Whitefield, 2002), or the use of corruption to cover the communist past in lustration policy (David, 2003). Corruption has also emerged as an important problem across the CEE countries in the juridical system as well (Grodeland, 2005).

Lízal and Švejnar (2000) showed that problems with soft-budget constraints persist in the Czech economy, mainly via the banking sector. We can still agree that some constraints persist and that the Czech procedures are far from being completely transparent, simple and lucid, but are, more importantly, also far from establishing an environment that 
minimizes the incentives to go around the rules even in the absence of punishment. However, as of 2014 and given the data about the widespread perception of corruption in the Czech Republic, one can conclude that this environment has evidently not been established successfully. Cisar (2003) has described practical recommendations for the use of information technologies in the public sector to minimize corruption.

Transparency International conducts an annual survey of corruption environment in all countries. According to data for last year, the Czech Republic ranked number 57 in perception of corruption, with 48 points, along with Namibia, Croatia and Bahrain. This represents a worsening from 2012, when the Czech Republic ended up in 54th place.

Other results of this organization show that:

- $95 \%$ of the Czech population consider corruption to be widespread,

- $8 \%$ of respondents were asked for a bribe or a bribe was expected from them in the last year, which is twice the European average

- $71 \%$ of Czech companies (the highest proportion in the EU) state that corruption is a major obstacle to their business.

- $12 \%$ of the population thinks the government's effort to fight against corruption is successful

- Only $15 \%$ of citizens of the opinion that a successful prosecution can dissuade people from corruption ${ }^{4}$.

- For completeness, an overview of the main Economic Indicators (Eurostat) is reported here:

- GDP per capita (2012) - 20,300 EUR

- GDP at current market prices (2012) - 152.9 billion EUR

- Economy and shadow economy (2013 estimate) - 15.5\% of GDP (Schneider et al., $2010)^{5}$.

According to Schneider et al (2010) and Buehn, Schneider (2011), eastern countries like Bulgaria, Cyprus, Latvia, Lithuania, including the Czech Republic, have a higher shadow economy than "old" countries like Germany, Austria, Belgium and Italy. According to GfK research from October, 2009 (GfK, 2010), which analyzed the corruption and corruption climate in the Czech Republic, 74\% of Czechs did not agree with corruption and saw it as amoral; however, the number of people who gave a bribe actually rose from $24 \%$ in 2006 to $35 \%$ in 2009 . In 2009 , almost half the population (48\%) declared that they gave a bribe at least once, while 13\% stated that they gave bribes repeatedly. Almost two-thirds of respondents (65\%) stated that they agree that getting a state contract without a bribe is impossible (Table 1). Also, since 2006, people have started to perceive the business sector as the sixth most corrupt field after political parties, government offices and ministries, government and the juridical system (GfK, 2010).

\footnotetext{
${ }^{4} \mathrm{http} / /$ ec.europa.eu/dgs/home-affairs/what-we-do/policies/organized-crime-and-human-trafficking/corruption/anti-corruption-report/docs/2014_acr_czech_republic_factsheet_en.pdf.

${ }^{5}$ In 2012 and 2011, the shadow economy accounted for 16.4\% of GDP (Schneider et al., 2010).
} 
Table 1: Areas with the largest share of corruption in the Czech Republic

\begin{tabular}{|c|l|l|l|l|l|l|}
\hline No & year 1998 & year 2001 & year 2002 & year 2003 & year 2006 & year 2009 \\
\hline 1 & offices & offices & offices & offices & offices & politician parts \\
\hline 2 & judiciary & judiciary & health service & health service & police & offices \\
\hline 3 & health service & police & police & police & government & ministry \\
\hline 4 & police & health service & judiciary & judiciary & politician parts & government \\
\hline 5 & service & ministry & customs & customs & ministry & judiciary \\
\hline 6 & education & customs & ministry & ministry & $\begin{array}{l}\text { business } \\
\text { community }\end{array}$ & $\begin{array}{l}\text { business } \\
\text { community }\end{array}$ \\
\hline 7 & hotel industry & banking & education & education & judiciary & police \\
\hline 8 & army & army & banking & banking & health service & health service \\
\hline 9 & & education & army & army & customs & army \\
\hline 10 & & & & & education & education \\
\hline 11 & & & & & army & customs \\
\hline 12 & & & & & banking & banking \\
\hline 13 & & & & &
\end{tabular}

Source: GfK, 2010

Furthermore, research organized by a leading research agency, Ipsos, that took place in the Czech Republic in 2011 showed that corruption is perceived as one of the main problems in the country. According to the survey, the majority of the respondents believed that corrupt people support each other and, according to opinion polls, the Czech government has no real interest in combating corruption. According to the respondents, corruption was most widespread among political parties. It reflected the fact that, according to the population, improving the poorly configured system, changes in the state and the reform of public administration could contribute to reducing corruption.

In addition to the above research, a study on corrupt behaviour was conducted among Czech politicians and businessmen in 2007. The research was conducted in collaboration with leading research agencies and the Institute of Sociology of the Academy of Sciences. Corruption and fraud is also perceived by the Edelman Trust Barometer as the main reason for distrust in both businesses and government institutions in the Czech Republic (Edelman, 2013).

The first part of the survey examined the issue of bribery. It appeared that most bribes are offered by medium-sized companies with Czech owners. In contrast, most bribes were reported as being requested by ministers, police officers and judges. When asked whether companies that take bribes deliver better products or services, the answers were as follows (Figure 2). 
Figure 2: Corruption and its impact on the quality of goods and services

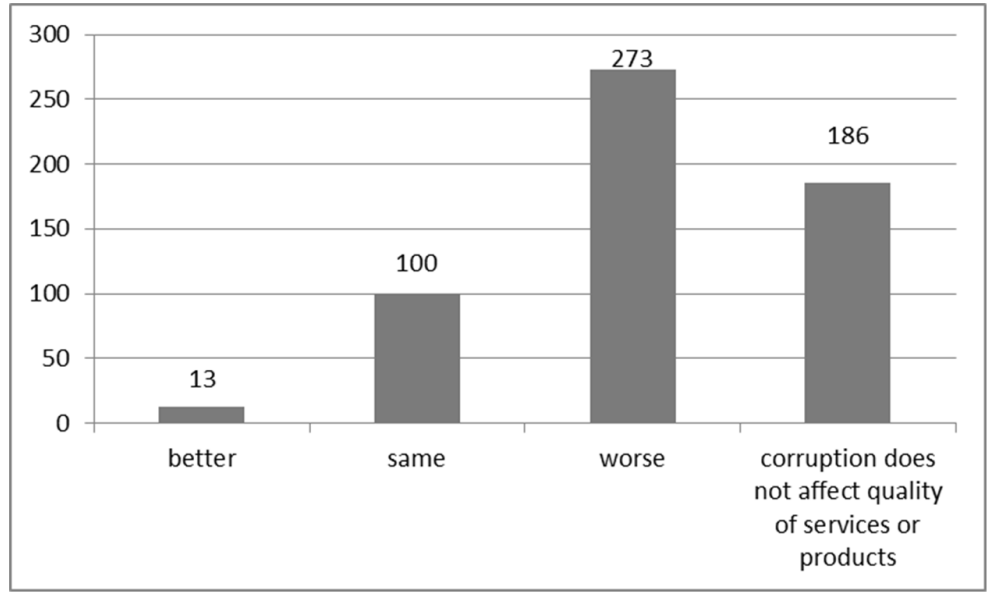

Source: Smith et al. (2007)

According to the results of the above research, one could say that one of the main reasons why corruption is so widespread in the Czech Republic is due to a high level of bureaucracy. The respondents reported greater transparency in contracts and stricter laws as one of the possible ways to fight corruption.

According to this research it may seem that corruption has deep roots in Czech society. Corruption and fraud is also perceived by the Edelman Trust Barometer as the main reason for distrust in both businesses and government institutions in the Czech Republic, yet on a different scale - government is trusted almost twice as much less than business because of corruption (Edelman, 2013). Czech people, however, undermine "transparency" - these issues are a problem locally for only $3 \%$ of respondents in government institutions and $12 \%$ in business. This discrepancy clearly shows that, instead of increasing the "transparent behaviour" of corporations and companies, Czechs prefer to talk about "anti-corruption" attitudes, because "corruption" is a widespread and known practice, which can be easily portrayed and framed as an ethical or socially responsible goal for both government policies and businesses (Figure 3 and Figure 4). 
Figure 3: Corruption/fraud as a reason for distrust in business and government in the Czech Republic

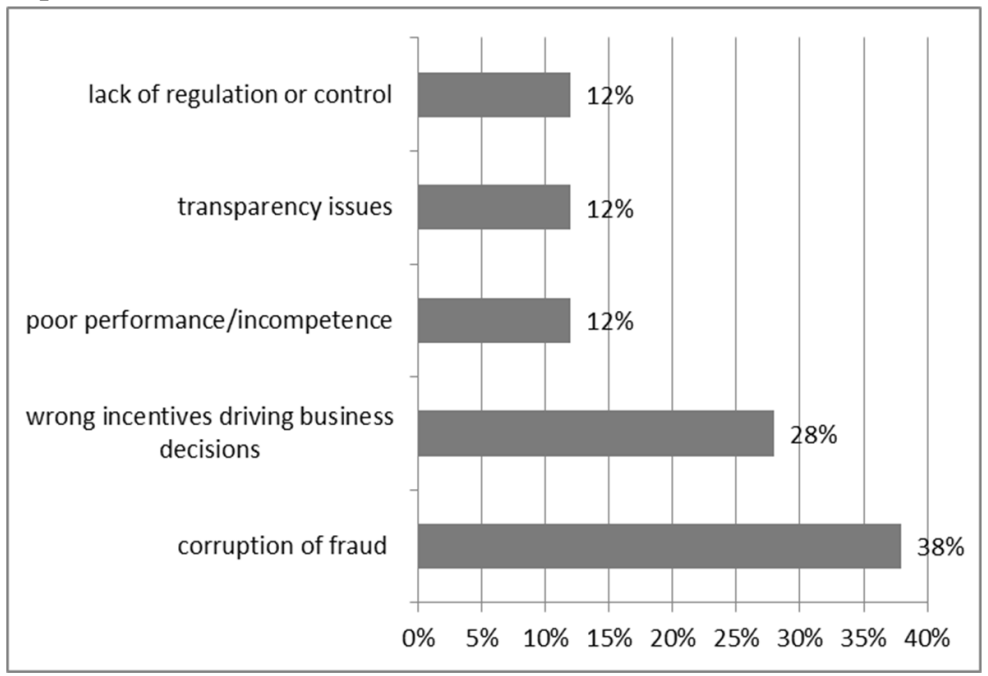

Source: Edelman, 2013

Figure 4: Corruption/fraud as a reason for distrust in government in the Czech Republic

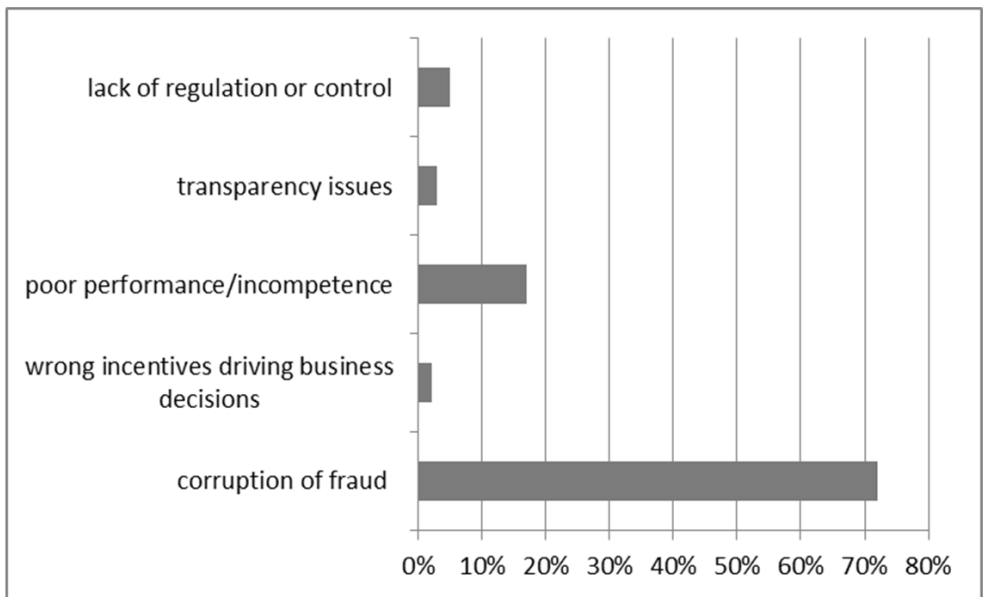

Source: Edelman, 2013

In addition to TI CZ, which deals with the fight against corruption, and especially monitoring corruption in the Czech Republic, there are other organizations trying to fight corruption. One of these is the "Endowment Fund Against Corruption", whose founders are entrepreneurs Karel Janeček (RSJ company founder and CEO), Stanislav Bernard (Bernard Brewery CEO) and well-known Czech actor, Jan Kraus. This organization was 
also co-founded by Karel Randák, a former state official, and Radim Jančura, CEO of Student Agency (a transportation company). There is also "Foundation against Corruption", which aims to fight corruption and reveal corruption and cases in the Czech Republic. NFPK is also supported by other Czech businessmen, such as Jannis Samaras (Kofola) or Libor Winkler (RSJ) (DKK, 2013).

The name Karel Janeček is not only connected with NFPK but also with the project called "Positive Evolution". Janeček launched a massive advertising campaign called "Waves of Evolution", with simple print advertisements featuring claims like "Do not be afraid of the truth". The campaign was criticised as pseudo-philosophical and unclear (Kasl Kollmanova, 2013, and Koutník, 2012). Kasl Kollmannová (2013) examined the rising popularity of the buzz-word "anti-corruption" in Czech media in 2005-2012, and also proved that the concept of "anti-corruption values" is used as a popular marketing and branding label used to enhance consumer loyalty to brands and as a marketing differentiation tool (in private, public or non-governmental companies and institutions). Anti-corruption rhetoric has been widely used by the new market-oriented political parties (Lees-Marshment, 2009 - see the description and also critique of this model on p. 42-48) in the Czech Republic, namely Věci veřejné (Public Affairs, 2010) and ANO (the party led by business leader and multi-billionaire tycoon, Andrej Babiš, 2013).

\section{Methodology and research design}

This article aims, among other things, to obtain information about the state of corruption in enterprises in the Czech Republic and map the behaviour of entrepreneurs and characteristic manifestations of corruption in the company. The research employed a questionnaire. The questionnaire consisted of open and closed questions (Řezanková, 2010), which were distributed among randomly selected Czech companies across various sectors.

The questionnaire aimed to extend and support qualitative research case studies.

The research methodology and design addressed the question of whether respondents met corruption directly or indirectly, whether their current employer was actively fighting against corruption, who in their enterprise most often felt a victim of corruption and whether they perceive corruption as a means for economic growth of the company. A questionnaire was conducted in early 2014, and was evaluated by statistical methods, which are described and applied below.

\section{Main results and discussions}

Our questionnaires were electronically distributed to 300 Czech companies across different sectors. The questionnaires were primarily designed for managers and other employees who move at higher firm levels. The questionnaires included both closed and open questions, with some of the questions marked as optional.

The main goal of this survey was to find the most frequent type of corruption based on firm-level evidence and to reveal personal experience with corruption in companies. In addition, the survey tried to describe the reasons for corruption behaviour on firm-level evidence, because this level is often neglected. 
The return rate was about 38\% (112 questionnaires). While checking, some irrelevant responses (or questionnaires) were eliminated. In total, 110 questionnaires were processed and analyzed.

The results were subjected to statistical analysis using MS Excel and SPSS software packages.

Figure 5 below reports the results of the questions, which aimed at understanding which positions were perceived by respondents to be the most affected by corruption (the question was compulsory and several possibilities could be mentioned).

Figure 5: Positions perceived by respondents to be the most affected by corruption

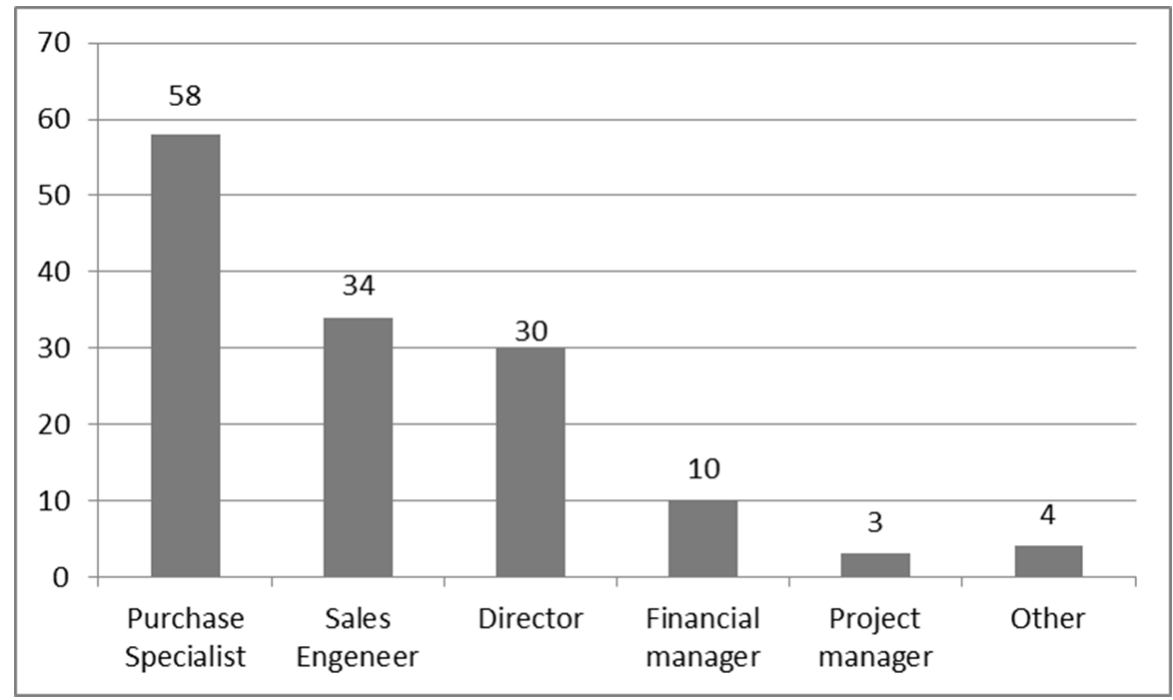

Source: Own results

According to the results obtained, it appears that buyers are most subject to corruption, while second place went to traders. Company directors are in third place.

Another part of the research was related to the type of corruption in Czech companies. First place went to bribery, which was closely followed by patronage. One could say that bribery predominates in the Czech firms as the most widespread form of corruption. The same outcomes were found in the field of public administration (Transparency International, 2013).

Figure 6 shows the corruption's kinds in Czech firms. The most widespread is bribery as well as clientelism. Also, lobbying seems to be a widespread in Czech firms. For the Czech people, lobbying is a big problem, because it is related to negative function (Kollmannová, Matušková, 2014). 
Figure 6: Most frequent forms of corruption in the Czech Republic

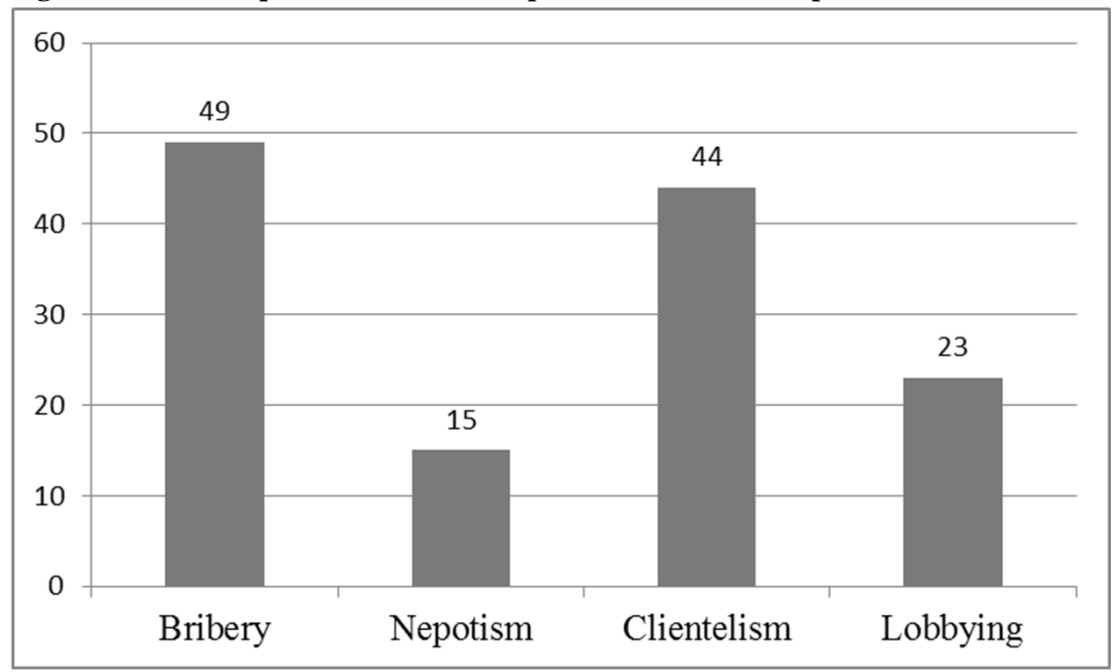

Source: Own results

The following table reports how many respondents have experienced corruption. It is obvious that only $1 / 4$ of the respondents met with corruption in their professional life (Table 2).

Table 2: Experience with corrupt behaviour at Czech firm level - answer frequency for the research

\begin{tabular}{|ll|cccc|}
\hline & Frequency & Percent & Valid Percent & Cumulative Percent \\
\hline \multirow{3}{*}{ Valid } & yes & 40 & 36,4 & 36,4 & 36,4 \\
& yes, but not direct & 45 & 40,9 & 40,9 & 77,3 \\
& no & 25 & 22,7 & 22,7 & 100,0 \\
\hline & Total & 110 & 100,0 & 100,0 & \\
\hline
\end{tabular}

Source: Own results

Further, the research focused on the proactive fight against corruption in Czech companies (Table 3). The results obtained are very interesting, since only $15.5 \%$ of companies are actively fighting against corruption, nearly $73 \%$ are not involved in this activity, and $11.8 \%$ did not want to answer this question or were not aware of any fight. This finding might indicate a lack of interest in the field of corruption or an unwillingness to undertake discussion of this slightly controversial topic. However, for those business enterprises which were fighting against corruption, the general public may not always be certain whether they are fighting corruption in reality or only on paper. Many businesses enterprises are subjected to guidelines and codes of conduct that regulate the behaviour in the workplace, for conducting contracts, etc. However, the actual results of these activities are not visible or measurable. 
Table 3: Experience with fighting against corruption at the Czech firm level - answer frequency for the research

\begin{tabular}{|ll|cccc|}
\hline & & Frequency & Percent & Valid Percent & Cumulative Percent \\
\hline \multirow{4}{*}{ Valid } & yes & 17 & 15,5 & 15,5 & 15,5 \\
& no & 80 & 72,7 & 72,7 & 88,2 \\
& do not know & 13 & 11,8 & 11,8 & 100,0 \\
\hline \multicolumn{2}{|c|}{ Total } & 110 & 100,0 & 100,0 & \\
\hline
\end{tabular}

Source: Own results

Some companies reported that they were fighting against corruption using the electronic auction system which was created to ensure transparent procurement. However, this system can easily be influenced and in practice can be manipulated to set specific requirements specifically designed to choose the previously agreed bidder. Although transparency seems ensured, there still remains room for corruption.

Table 4 shows information about whether, in the respondents' experience, corruption might lead to a better economic situation. In total, 65 respondents answered positively and 36 expressed neutrality. Either they did not want to talk about the situation or were uninterested in the impact of corruption on the economic situation of their company.

Table 4: Economic situation - answer frequency for the research

\begin{tabular}{|ll|cccc|}
\hline & & Frequency & Percent & Valid Percent & Cumulative Percent \\
\hline \multirow{3}{*}{ Valid } & yes & 65 & 59,1 & 59,1 & 59,1 \\
& no & 9 & 8,2 & 8,2 & 67,3 \\
& do not know & 36 & 32,7 & 32,7 & 100,0 \\
\hline \multicolumn{2}{|c|}{ Total } & 110 & 100,0 & 100,0 & \\
\hline
\end{tabular}

Source: Own results

The respondents considered a better economic situation to be increased profits or increased turnover, possibly the recruitment of new staff. Basically, they linked the better economic situation of the company to business growth, as these three basic indicators (increased turnover, profit and number of employees) are considered essential in the growth of companies (Koudelková, 2013).

Based on this information, the dependence of improving the economic situation from firm-level corruption was further investigated using the chi-square test of independence for two nominal variables. Since we are testing the independence of two variables, the following two hypotheses were formulated:

$\mathrm{H} 0$ : Improving the economic situation of the company is not dependent on the presence of corruption in the company

H1: Improving the economic situation of the company is dependent on the occurrence of corruption in the company

The following table (Table 5) shows the frequency, i.e. statistical testing of the second degree: 
Table 5: Corruption in your company * Better economic situation - Cross tabulation for Chi square test

\begin{tabular}{|ll|ccc|c|}
\hline & & \multicolumn{3}{|c|}{ Better economic situation } & \multirow{2}{*}{ Total } \\
\cline { 3 - 5 } & yes & no & cannot say & \\
\hline \multirow{2}{*}{ Corruption in } & yes, often & 33 & 8 & 12 & 53 \\
your company & one or two times & 12 & 7 & 16 & 35 \\
& no, never & 4 & 15 & 3 & 22 \\
\hline Total & 49 & 30 & 31 & 110 \\
\hline
\end{tabular}

Source: Own results

Table 6 reports the results of chi-square test. The test was run at a significance level of 0.01 . According to the results obtained, 0 cells $(0.0 \%)$ expected a count of less than 5 . The minimum expected count was 6.00; thence, the conditions of the chi-square independence test were fulfilled.

Table 6: Results of Chi-Square Tests

\begin{tabular}{|l|ccc|}
\hline & Value & df & Asymp. Significant (2-sided) \\
\hline Pearson Chi-Square & $31.103^{\mathrm{a}}$ & 4 & .000 \\
Likelihood Ratio & 28.202 & 4 & .000 \\
N of Valid Cases & 110 & & \\
\hline
\end{tabular}

a) 0 cells $(0.0 \%)$ have expected count less than 5. The minimum expected count is 6.00.

Source: Own results

We can reject the null hypothesis $\mathrm{H} 0$ in favour of the alternative hypothesis $\mathrm{H} 1$, while we reject it at the $1 \%$ significance level. It appears that improving the economic situation of the company is dependent on the occurrence of corruption in the company. It is clear from the results above that every enterprise met with a certain type of corruption during the time it spent on the market, either directly or indirectly.

Another phenomenon that must be taken into account is that many Czech entrepreneurs regard corruption as the driving engine of the economy and its growth. This idea was originally formulated by Lui (1985) who devised it for developing countries. It is therefore evident that the basic paradigm carried over from the primary research remains in force even after almost 30 years.

It becomes apparent from our results that corruption at the firm level in the Czech Republic is as dynamic as the one at the country level. Both directors and top business leaders are engaged in corruption. Nevertheless, it cannot be fully proved that employees are actively involved in corruption with the full awareness of the management of the companies. In most cases, corporate culture prohibits such conduct and threatens by implementing tough sanctions. Company management often pointed to the fact that corruption was against their beliefs, but subsequently added, however, that they had some (direct or indirect) experience with corruption.

Of course, companies and clients can use anti-corruption foundations and other organizations to help them detect and combat corruption. According to the information presented in the media, this is done mostly on the client side, due to the fact that there is fairly broad awareness about corruption in the Czech Republic. The question is, however, how 
the GDP and the entire national economy in the Czech Republic would manage without the existence of corruption.

It is evident that, at the country level, the most frequent type of corruption in the Czech Republic is bribery. However, according to our survey results, firm-level bribery also promotes clientelism, lobbying and, in some cases, nepotism. Table 7 shows the most characteristic features and most common types of corruption occurring in the Czech Republic.

Table 7: Basic classification of firm-level corruption in the Czech Republic

\begin{tabular}{|ll|c|c|c|c|}
\hline \multirow{2}{*}{} & \multicolumn{4}{|c|}{ Forms of corruption } \\
\cline { 3 - 6 } & Tangible & \multicolumn{2}{|c|}{ Intangible } \\
\cline { 2 - 6 } & Bribery & Clientelism & Lobbying & Nepotism \\
\hline \multirow{3}{*}{$\begin{array}{l}\text { Basic forms } \\
\text { Go corruption transfers }\end{array}$} & Gifts up to 50 ths. CZK & $\mathrm{X}$ & & & \\
& Gifts above 50 ths. CZK & $\mathrm{X}$ & & & \\
& Counter offers & & $\mathrm{X}$ & $\mathrm{X}$ & $\mathrm{X}$ \\
& Tenders & & $\mathrm{X}$ & & \\
& Employment & & $\mathrm{X}$ & & $\mathrm{X}$ \\
& Helping the interest groups & & $\mathrm{X}$ & $\mathrm{X}$ & \\
\hline
\end{tabular}

Source: Own results

\section{Conclusion}

Discussion on the topic of corruption has developed both in the Czech and international business environment, as well as in the research literature. There is a plethora of reflections and analyses on this subject, and despite the wide theoretical base, there is still no universal approach to tackling corruption.

There are several studies that deal with the merger of corruption and the economic development of a country or economic growth. Basically, there are two main pathways of research (Aidt, 2009). The research results of the first pathway speak in favour of corruption. According to them, corruption contributes to the economic boom (Egger, Winner, 2005; Leff, 1964). Tolerating corruption can even be positive, the practical examples of which can be seen in the example of ethnically divided Macedonia. This state represents the most corrupt state - in a state of total state corruption. Quite paradoxically, corrupt political environment has a positive effect on ethnic conflicts and preventing ethnic struggles (Green, Ward, 2004; Hislope, 2008).

The other pathway of research says that corruption is ineffective and inefficient and has a positive impact on economic development, see e.g. Rose-Ackerman (1999), Buchanan and Tullock (1962), in particular, at the micro level, Aidt (2009). In addition, it is a view which has long been rooted among the general society (Aidt, 2009). Although the corruption is generally viewed as negative, there might be some cases in which it can be tolerated because it can serve as a means to supporting the interests of and prevent from hindering economic growth (lobbying). Examples of such cases can be found in Italy (Holmes, 2003). 
According to the results of our research, it can be shown that corruption is widespread at the firm level in the Czech Republic. This trend can be attributed to the negative impact of the financial crisis, during which companies sought to eliminate and increase sales and market share. Only $15.5 \%$ of the surveyed firms fight against corruption. The others do not engage in fighting corruption or express their neutrality on the subject.

If one considers the types of corruption occurring in companies in the Czech Republic, it has to be noted that, in addition to the commonly widespread bribery, cronyism and lobbying $^{6}$ also play significant roles in the Czech Republic. People in the Czech Republic are accustomed to give and receive bribes for their help as a form of reward which creates socially and economically important networks and this is important for them in terms of their business and in obtaining high social status.

As stated above, there are two basic currents of corrupt mentality mentioned in the literature. When one looks at the facts resulting from our research, it becomes apparent that our results are closer to those researchers who proclaim that corruption might be an effective tool for supporting national economies. Corruption certainly represents a serious problem, especially on the ethical level, as shown by Kaufmann and Wei (1999) and Fisman and Svensson (2007), who conducted a survey of Ugandan firms. According to them, a one per cent increase in the bribery rate is associated with a three per cent reduction in firm growth, but one has to remember that there are two sides to every coin.

Let us imagine the following situation: one company wants to award a contract, while another company seeks to obtain a contract. Should the second company get the contract, it will increase its sales and profits, provide work for its employees and pay taxes to the state coffers. If an employee of the contract-providing company accepts a bribe, the bribe is not taxed and it may happen that the contract-providing company might be damaged (e.g. incompetent contractor, higher costs, late completion of the contract, bad reputation, etc.). However, if one thinks beyond this limited interpretation, it becomes apparent that the person who received the bribe for giving the contract to the specific company obtained free funds which are not in any way taxed (no VAT, corporate income tax, personal income tax are paid on bribes) or which will gradually return to the economy. One can say that at the moment of bribing the state loses the taxes, but it can be argued that this money will stimulate the economy by returning fully into circulation and thus will help the state to obtain additional revenues from taxes and fees. This is only a theoretical example of how bribes and corruption are often perceived in Czech society, in which they are deeply rooted, a fact which makes them very difficult to fight.

\section{References}

Ades A., Di Tella, R. (1999). Rents, competition, and corruption. American Economic Review, 89, 982-993.

Aidt T. S. (2009). Corruption, institutions, and economic development. Oxford Review of Economic Policy, 25(2), 271-291.

\footnotetext{
${ }^{6}$ Although it might seem that lobbying is nowadays a formal legal act, it is still viewed negatively in the Czech Republic and, despite its definition, is considered a subspecies of corruption, especially between business and politics (Kasl Kollmannová and Matušková, 2014).
} 
Batory, A. (2012). Why do anticorruption laws fail in Central Eastern Europe? A target compliance perspective. Regulation \& Governance, 6(1), 66-82.

Berg V. Sanford, Liangliang, J. and Chen, L. (2012). Regulation and corporate corruption: new evidence from the telecom sector. Journal of Comparative Economics, 40(1), 22-43. Besley T., McLaren, J. (1993). Taxes and bribery: the role of wage incentives. Economic Journal London, 103, 119-119.

Birčiáková, N., Stávková, J. and Antošová, V. (2013). Income (In) Justice In The Czech Republic. DANUBE: Law and Economics Review, (3), 185-199.

Bliss Ch., Di Tella, R. (1997). Does competition kill corruption? Journal of Political Economy. 105, 1001-1023.

Bornstein M. (1999). Framework Issues in the Privatisation Strategies of the Czech Republic, Hungary and Poland. Post-Communist Economies, 11, 47-77. doi:10.1080/14631379996048.

Buchanan J., Tullock, G. (1962). The Calculus of Consent: Logical Foundations of Constitutional Democracy. Ann Arbor, University of Michigan Press, MI.

Buehn A., Schneider, F. (2011). Shadow economies around the world: novel insights, accepted knowledge, and new estimates. International Tax and Public Finance, 19(1), 139-171.

Cisar O. (2003). Strategies for Usin Information Technologies Curbing Public Sector Corruption: The Case of the Czech Republic. Open Society Institute, Budapest.

Cooray A., Schneider, F. (2013). How Does Corruption Affect Public Debt. An Empirical Analysis, No. 2013-22.

David R. (2003). "Lustration Laws in Action: The Motives and Evaluation of Lustration Policy in the Czech Republic and Poland (1989-2001)." Law \& Social Inquiry, 28(2), 387-439. doi:10.1111/j.1747-4469.2003.tb00197.x.

Edelman. (2013). Trustbarometer 2013. Retrieved March 19, 2013, from http://www.edelman.com/trust-downloads/global-results-2/. Local data for the Czech Republic (internal document).

Egger P., Winner, H. (2005). Evidence on Corruption as an Incentive for Foreign Direct Investment. European Journal of Political Economy, 21, 932-52.

Emerson, M. P., (2006). Corruption, competition and democracy. Journal of Development Economics, 81, 193-212.

Evans G., Whitefield, S. (1998). The Structuring of Political Cleavages in Post-Communist Societies: the Case of the Czech Republic and Slovakia. Political Studies, 46(1), 115-139. doi:10.1111/1467-9248.00133.

European Commission. (2014). Corruption. Report. Special Eurobarometer 397. Retrieved February, 2014 from http://ec.europa.eu/public_opinion/archives/ebs/ebs_397_en.pdf.

Favre B. V., Puthod, C. T. (2013). Resource and Skill Transfers in Subcontractor SME Acquisitions: Influence on the Long-Term Performance of Acquired Firms. European Management Review, 10(3), 117-135.

Fisman R., Svensson, J. (2007). Are Corruption and Taxation Really Harmful to Growth? Firm Level Evidence. Journal of Development Economics, 83(1), 63-75. 
Flatten T. Ch., Isabell, G. G., Brettel, M. (2011). Absorptive capacity and firm performance in SMEs: The mediating influence of strategic alliances. European Management Review, $8(3), 137-152$.

GfK. (2010). Korupční klima v České republice. GfK research. Retrieved April 12, 2014, from http://www.transparency.cz/doc/projekty/NIS/Konference/Martin_Mravec_GfK_Korupcni_klima_v_Ceske_republice.pdf.

Graeff P., Mehlkop, G. (2003). The impact of economic freedom on corruption: different patterns for rich and poor countries. European Journal of Political Economy, 19, 605-620. Graycar, A., Prenzler, T. (2013). Understanding and Preventing Corruption. Palgrave Macmillan.

Green P., Ward, T. (2004). State Crime. Governments, Violence and Corruption, London a Sterling. Pluto Press.

Grodeland, A. (2005). Fighting Corruption and Promoting Integrity in Public Procurement. Paris: OECD.

Gupta, N., Ham J. C., Švejnar, J. (2000). Priorities and Sequencing in Privatization: Theory and Evidence from the Czech Republic.

Hamadi M. (2010). Ownership concentration, family control and performance of firms. European Management Review, 7(2), 116-131.

Herzfeld, T., Weiss, C. (2003). Corruption and legal (in) effectiveness: an empirical investigation. European Journal of Political Economy, 19(3), 621-632.

Hislope R. (2008). Corrupt Exchange in Divided Societies. The Invisible Politics of Stability in Macedonia in: Orenstein, M. A., Bloom, S., Lindstrom, N. (eds.). Transnational Actors in Central and East European Transitions, Pittsburgh, University of Pittsburgh Press, 142-161.

Holmes, L. (2003). Political Corruption in Central and Eastern Europe. Bull, M. J., Newell, J. L. (eds.). Corruption in Contemporary Politics, New York, Palgrave Macmillan, 193-206.

Jancsics, D. (2013). Petty corruption in Central and Eastern Europe: the client's perspective. Crime, Law and Social Change, 60(3), 319-341. doi:10.1007/s10611-0139451-0.

Janowicz M., Piaskowska D. and Trojanowski, G. (2004). Role of strategic investors in Polish companies: Catalysts for organizational change or opportunists?. European Management Review, 1(2), 145-156.

Johnson S., Kaufmann D. and Shleifer, A. (1997). The Unofficial Economy in Transition. Brookings Papers on Economic Activity. Brookings Institute, Washington, DC.

Jordan M. Jeffrey. (2002). Patronage and Corruption in the Czech Republic. SAIS Review, 22(2), 19-52. doi:10.1353/sais.2002.0038.

Kaufmann D., Wei, S. J. (1999). Does "Grease Money" Speed Up the Wheels of Commerce? National Bureau of Economic Research, NBER Working Paper 7093.

Kaufmann D. (2010). Can Corruption Adversely Affect Public Finances in Industrialized Countries. Brookings.

Klitgaard, R., Maclean-Abora, R. (2000). Corrupt Cities, ICS. Profess Consulting. 
Kasl Kollmannová, D. (2012). CEO and Businesses are Losing Trust: Comparison of EU, USA, Czech and Slovak Republic. Central European Business Review, 1(1), 7-13.

Kasl Kollmanová, D. (2013). The Growth of Anti-Corruption Attitudes in Czech Marketing Communication and PR: Anti-Corruption Fight as Marketing Tool. Central European Business Review, (1), 15-20.

Kasl Kollmannová, D., Matušková, A. (2014). Public affairs in the Czech Republic: an exploratory study of the current situation. Journal of Public Affairs, 14, 54-66.

Koudelková, P. (2013). Innovation factors influencing the growth of small and mediumsized enterprises. Brno University of Technology. Brno. Czech Republic.

Koutník O. (2012). Karel Janeček na naivních vlnách? Česká Pozice. 2013.

Lambsdorff J. G. (2007). The Institutional Economics of Corruption and Reform: Theory, Evidence and Policy. Cambridge University Press, Cambridge.

Leff N. (1964). Economic Development through Bureaucratic Corruption. American Behavioral Scientist, 8(3), 8-14.

Lees-Marshment, J. (2009). Political Marketing: Principles and Applications. Routledge. Li, H., Xu, L. C. and Zou, H. (2000). Corruption, income distribution, and growth. Economics and Politics, 12, 155-182.

Lízal L., Švejnar, J. (2000). Financial conditions and investment during the transition: evidence from Czech firms. CERGE-El Working Paper No. 153.

Lízal L., Kocenda, E. (2001). State of corruption in transition: case of the Czech Republic. Emerging Markets Review, 2(2), 138-160. doi:10.1016/S1566-0141(01)00014-0.

Lui, F. T. (1985). An equilibrium queuing model of bribery. Journal of Political Economy, 93, 760-781.

Mauro, P. (1995). Corruption and growth. Quarterly Journal of Economics, 110, 681-712. Merton K. R. (1961). Social Problems and Sociological Theory. Merton, R. K., Nisbet, A. R. (eds.). Contemporary Social Problems, New York: Harcourt, Brace and World, Inc., 697-737.

Mo P. H. (2001). Corruption and economic growth. Journal of Comparative Economics, 29, 66-97.

Mravec, M. (2012). Korupční klima v České republice (Corruption Climate in the Czech Republic). Transparency International. Retrieved December 18, 2012, from http://www.transparency.cz/doc/projekty/NIS/Konference/Martin_Mravec_GfK_Korupcni_klima_v_Ceske_republice.pdf.

Murphy K., Shleifer A. and Vishney, R. (1991). The allocation of talent: implications for growth. Quarterly Journal of Economics, 106, 503-530.

Nandini, G., Ham, J. C., Švejnar, J. (2008). Priorities and sequencing in privatization: Evidence from Czech firm panel data. European Economic Review, 52(2), 183-208.

Nguyen, T. T., Van Dijk, M. (2012). Corruption, growth, and governance: Private vs. state-owned firms in Vietnam. Journal of Banking \& Finance, 36(11), 2935-2948.

North, D. C. (1990). Institutions, Institutional Change and Economic Performance. Cambridge University Press, Cambridge. 
OČKO, P. (2012). Ministerstvo průmyslu a obchodu. Tisková konference VŠE a MPO, Analýza GEM: Př́prava nové Koncepce MSP 2014+. Praha. Retrieved from http://www.mpo.cz/ dokument 104425.html.

OECD. (2010). OECD Economic Surveys: Czech Republic 2010. OECD Publishing.

Otáhal T. (2006). Ekonomická analýza definice korupce. Národohospodářský obzor, 4(1), $50-60$.

Paldam, M. (2002). The cross-country pattern of corruption: economics, culture and the seesaw dynamics. European Journal of Political Economy, 18, 215-240.

Pieroni, L., d'Agostino, G. (2013). Corruption and the effects of economic freedom. European Journal of Political Economy, 29, 54-72.

Rose-Ackerman S. (1999). Corruption and Government, Causes, Consequences and Reform. Cambridge, Cambridge University Press.

Řezanková, H. (2010). Analýza dat z dotazníkových šetření. Professional Publishing.

Schneider F., Buehn A. and Montenegro, C. (2010). Shadow Economies All Over the World: New Estimates for 162 countries from 1999-2007, World Bank Policy Research Working Paper No. 5356.

Schneider, F. (2014). In the Shadow of the State - The Informal Economy and Informal Economy Labor Force. DANUBE: Law and Economics Review, (4), 227-248.

Smith, J. (1985). Market motives in the informal economy, in: Gaertner, W. and Wenig, A. (eds.): The economics of the shadow economy, Heidelberg: Springer Publishing Company, 161-177.

Smith, M. et al. (2007). Corruption in the Czech Republic: Politicians and Managers' Perceptions. Retrieved from http://www.dbm.cz/pfile/1Corruption_report_en.pdf.

Stephen F. K. (2007). Measuring corruption: A critique of indicators in Eastern Europe and Central Asia. Journal of Public Policy, 27, 255-91.

Staniszkis, J. (2009). O moci a bezmoci. Brno, Centrum pro studium demokracie a kultury. Transparency International. (2013). How corrupt is your country? (n.d.). Retrieved February 15, 2014, from http://transparency.org/cpi2013.

Vedres, B. (2007). Pathways from postsocialism: ownership sequence and performance of firms in Hungary, 1991-1999. European Management Review, 4 (2), 93-105.

Wallace, C., Latcheva, R. (2006). Economic transformation outside the law: corruption, trust in public institutions and the informal economy in transition countries of Central and Eastern Europe. Europe-Asia Studies, 58(1), 81-102.

Wang, Y., You, J. (2012). Corruption and firm growth: Evidence from China. China Economic Review, 23(2), 415-433.

Zelený, M. (2003). Sítě malých a středních podniků - Interfiremní spolupráce jako zdroj konkurenceschopnosti. Sborník préednášek z mezinárodní konference JAKOST 2003. Ostrava: Dům techniky. ISBN 80-02-01558-4.

Zuzowski, R. (2004). Corruption in Eastern Europe. South African Journal of International Affairs, 11(2), 129-142. 